\title{
Article
}

\section{Comparative Polyphenol Composition, Antioxidant and Anticorrosion Properties in Various Parts of Panax ginseng Extracted in Different Solvents}

\author{
Ramalingam Malathy ${ }^{1,+}{ }^{(D}$, Mayakrishnan Prabakaran ${ }^{2,+}$, Kathirvel Kalaiselvi ${ }^{3}$, Ill-Min Chung ${ }^{2,+}$ and \\ Seung-Hyun Kim ${ }^{2, *}$
}

1 Department of Civil Engineering, Sona College of Technology, Salem 636005, Tamil Nadu, India; malathycivil@sonatech.ac.in

2 Department of Crop Science, College of Sanghuh Life Science, Konkuk University, 120 Neungdong-ro, Gwangiin-gu, Seoul 05029, Korea; prabakaran@konkuk.ac.kr (M.P.); imcim@konkuk.ac.kr (I.-M.C.)

3 Department of Chemistry, J.K.K. Nataraja College of Arts and Science, Namakkal 638183, Tamil Nadu, India; kalaiselvi_k@jkkn.ac.in

* Correspondence: kshkim@konkuk.ac.kr

+ Contributed equally to this work.

Citation: Malathy, R.; Prabakaran, M.; Kalaiselvi, K.; Chung, I.-M.;

Kim, S.-H. Comparative Polyphenol Composition, Antioxidant and Anticorrosion Properties in Various Parts of Panax ginseng Extracted in Different Solvents. Appl. Sci. 2021, 11, 93. https://dx.doi.org/10.3390/ app11010093

Received: 5 October 2020

Accepted: 21 December 2020

Published: 24 December 2020

Publisher's Note: MDPI stays neutral with regard to jurisdictional claims in published maps and institutional affiliations.

Copyright: () 2020 by the authors. Licensee MDPI, Basel, Switzerland. This article is an open access article distributed under the terms and conditions of the Creative Commons Attribution (CC BY) license (https: / / creativecommons.org/ licenses/by/4.0/).

\begin{abstract}
Panax ginseng C.A. (P. ginseng) Meyer has been in use since ancient times for its therapeutic activities. Although several studies have investigated the roles of phytoconstituents in human and animal health, no comparative studies have been conducted to test the efficacy of $P$. ginseng leaf, fruit and root. Therefore, this study aimed to identify the antioxidant and anticorrosion activities of ginseng prepared using five different solvents. The methanolic fruit extract showed comparatively good activity in all assays. The total phenolic content (TPC) was higher in fruit $(95.21 \mathrm{mg} / \mathrm{g})$, followed by leaf $(39.21 \mathrm{mg} / \mathrm{g})$ extracted in methanol solvent compared other solvents. The total flavonoid content (TFC) of fruit methanolic extract was $50.21 \mathrm{mg} / \mathrm{g}$, which was followed by fruit extracted in ethanol $(41.33 \mathrm{mg} / \mathrm{g})$. The same phenomenon was observed in all antioxidant studies. Through Ultrahigh Performance Liquid Chromatography (UHPLC), the presence of 23 phenolic components categorized as hydroxycinnamic acids, hydroxybenzoic acids and a few other groups that play a vital role in antioxidation was identified. Phenols such as chlorogenic acid $(1002.2 \mu \mathrm{g} / \mathrm{g})$, gentisic acid $(854.21 \mu \mathrm{g} / \mathrm{g})$ and rutin $(165.32 \mu \mathrm{g} / \mathrm{g})$ were found in higher amounts in fruit whereas leaf showed significant amounts of $m$-coumaric acid $(185.32 \mu \mathrm{g} / \mathrm{g})$ and $p$-coumaric acid $(125.24 \mu \mathrm{g} / \mathrm{g})$. The anticorrosive property of the fruit extract of the ginseng with methanol as a solvent was analyzed for a copper specimen exposed to $1 \mathrm{M} \mathrm{HCl}$ medium and found to have $96 \%$ corrosion inhibition efficiency at a 1000-ppm concentration. The smooth surface of the specimen exposed to corrosive media shown in a field emission scanning electron microscope (FESEM) image confirms that the specimen was protected from corrosion, and energy-dispersive $\mathrm{X}$-ray spectroscopy (EDX) spectra show that the loss of $\mathrm{Cu}$ is reduced in inhibited metal surface. Atomic force microscopy (AFM) images and surface roughness factor also validate the corrosion inhibition characteristic of ginseng plant extract.
\end{abstract}

Keywords: ginseng; phenolic compounds; antioxidants; corrosion; copper; FESEM-EDX; AFM

\section{Introduction}

This deciduous perennial plant belongs to the Araliaceae family, which has 13 different species. The most important species originate from different places, such as Panax ginseng C.A. Meyer seen in China, Japan, Germany, Korea and Russia; Panax quinquefolius L. from American countries; Panax japonicas C.A. Meyer in Japan; Panax notoginseng (Burk.) F.H. Chen from China; Panax trifolius L. from Wisconsin to Nova Scotia; and Panax pseudoginseng Wallich, Panax major Ting and Panax omeiensis J. Wen from the eastern Himalayas and Nepal. The three different types of ginseng are produced from the cultivated Korean species Panax ginseng C.A. Meyer. Differences in harvest times and processing methods 
give rise to all three varieties [1-4]. Aromatic hydroxylated constituents, commonly known as polyphenols, are found in greens, fruits, herbs and vegetables. Many published reports have emphasized the influence of these compounds on human health [5-8]. These phenolic derivatives of one of the secondary metabolites (ginsenosides) are known to exert diverse biological properties, such as antibiotic, anti-tumor, antioxidant, and antimicrobial activities. Hence, the incorporation of these phenolic compounds into our daily diet helps to reduce the risk of numerous degenerative and chronic diseases [9]. Many bioactive elements such as phenolic components, ginsenosides, essential oils, proteins and polysaccharides are found in several varieties of ginseng. Different types of ginseng such as red, white and black ginseng are prepared from a single variety by following different manufacturing processes [10]. Fresh ginseng is steamed at $95-100^{\circ} \mathrm{C}$ for some time to produce red ginseng; dried in sunlight for a considerable amount of time to produce white ginseng; or steamed more than nine times for $3 \mathrm{~h}$ at $95-100{ }^{\circ} \mathrm{C}$ to produce black ginseng [11-13].

Diverse types of ginsenosides were identified in various studies which showed the importance of ginseng in pharmacology [14-16]. Ginsenosides are steroids, glycosides and triterpenoids saponins which can be separated into two categories: protopanaxadiol ginsenosides and protopanaxatriol ginsenosides. There are a wide variety of saponins, including Ra1-Ra3, Rb1-Rb3, MA-Rb2, Rc, MA-Rc, Rd, MA-Rd, Rg1-Rg3 and Rh1-Rh3, which have been separated using HPLC. In addition, they also encompass many other components, such as quinoquenosides (Q), malonyls (MA), ocotillol, protopanaxatriols (PPT), glucopyranosyl (Glc) and oleanolic acid (Ro) [17-19]. The effects of the human gamma herpes virus, Kaposi's sarcoma-associated herpes virus (KSHV) and Epstein-Barr virus (EBV) are inhibited by 20(R)-ginsenoside Rh2. Several researchers have also shown the importance of ginsenosides in treating diseases such as multicentric Castleman's disease, primary effusion lymphoma, Hodgkin's disease, nasopharyngeal carcinoma and AIDS-associated epidemic Kaposi's sarcoma [20-22]. Given the importance of plants as a source of bioactive compounds with biological importance, this study was designed to investigate the phenolic compounds present in Panax ginseng from Korea and to compare the antioxidant and antimicrobial activities of the phenolic compounds.

The significance of the ginseng fruit as a corrosion inhibitor for copper in acid medium was investigated. Corrosion of metals is an inevitable process which reduces the lifetime of the metals. There are many types of metals used for the day-to-day activities of human life [23-25]. One among the common metals used for many applications in industries is copper, due to its superior engineering properties [26]. Like all other metals, copper is also victim of corrosion due to the exposure to aggressive media, particularly acids $[27,28]$. To protect copper from corrosion, many green organic inhibitors from plants were identified and presented in recent literature [29,30]. Many plants were identified as corrosion inhibitors, particularly for copper corrosion under acid medium [31]. A few can be quoted particularly for inhibiting copper corrosion exposed to $\mathrm{HCl}$-for instance, Ligularia fischeri [32], Zenthoxylum alatum [33], Rhizopora apiculata [34], Lawsonia inermis [35] and Phoenix dactyligera [36]. In addition to the antioxidant nature of $P$. ginseng, its anti-corrosive property is also a focus of this paper. This paper optimizes the maximum inhibition efficiency of $P$. ginseng fruit extract in methanol at various concentrations from 100 to 1000 ppm in increments of $100 \mathrm{ppm}$. Weight loss, temperature studies and field emission scanning electron microscope (FESEM), energy-dispersive X-ray spectroscopy (EDX) and atomic force microscopy (AFM) analyses were carried out to confirm the anti-corrosive potential of ginseng.

\section{Materials and Methods}

\subsection{Collection and Extraction of Plant Materials}

The plant materials required for this research $(P$.ginseng) were collected from Seoul, Republic of Korea, in November 2019. The samples were washed thoroughly in running tap water to remove dust and sand particles. The test samples (root, leaf and fruit) were separated and dried at $303 \pm 1 \mathrm{~K}$ in a hot-air oven to remove moisture. The dried materials 
were powdered and extracted with respective solvents as described in a previous protocol [37,38]. Each sample (100 g) was extracted with $5 \times 2 \mathrm{~L}$ of each solvent (HPLC-grade water, methanol, ethanol, ethylene acetate and acetone) for $24 \mathrm{~h}$ and then stored in vacuo for the removal of solvents. The crude extracts obtained were resuspended in $0.5 \mathrm{~L}$ distilled water, to which $0.2 \mathrm{~L}$ of each solvent was added to extract it until a colorless solution evolved. At the end of extraction, all solvents were removed in vacuo, leaving the extracted sample for future use.

\subsection{Estimation of Total Phenols, Total Flavonoids and Individual Phenolic Compounds}

The total phenolic content (TPC) in all samples was estimated as per the method described by Liang et al. [39]. The procedure described by Prabakaran et al. [40] was followed for the detection of the quantity of flavonoids (total flavonoid content, TFC) in the test samples. The preparation and extraction of the phenolic compound were performed in accordance with the procedure of Prabakaran et al. [41]. The analysis of polyphenols by UHPLC (Thermo Accela UHPLC (Thermo, New York, NY, USA) using C18 Waters Symmetry $150 \times 4.6 \mathrm{~mm}^{2}, 5 \mu \mathrm{m}$, LiChrospher $250 \times 4.6 \mathrm{~mm}^{2}, 5 \mu \mathrm{m}$, and Phenomenex ${ }^{\circledR}$ Luna, $250 \times 4.6 \mathrm{~mm}^{2}, 5 \mu \mathrm{m}$, was able to identify hydroxybenzoic acid derivatives, hydroxycinnamic acid derivatives, flavonols and many other phenolic groups [42].

\subsection{Antioxidant Activity}

The nitric oxide radical-scavenging ability of the test samples was assessed in accordance with previously described methods by Boora et al. [43]. The free radical hydrogen peroxide $\left(\mathrm{H}_{2} \mathrm{O}_{2}\right)$ was scavenged by modifying the method from Hazra et al. [44] with some changes. The total antioxidant activity of the extracts was confirmed by using the phosphomolybdenum method as previously prescribed [45].

\subsection{Corrosion Studies}

\subsubsection{Weight Loss Analysis}

Weight loss analysis is a common method of determining corrosion inhibition efficiency of any inhibitor. In this method, the metal sample was cut into $3 \mathrm{~cm} \times 1 \mathrm{~cm} \times$ $0.5 \mathrm{~cm}$ size, polished well to remove the unwanted metals present on the surface and cleaned with acetone to eliminate moisture and impurities, and the initial weight of each specimen was noted. The prepared metal specimens were kept in beakers with $100 \mathrm{~mL}$ $\mathrm{HCl}$ solution with and without inhibitor in such a way that the metal should not have physical contact with the inner surface of the beakers. The specimens were submerged in $1 \mathrm{M} \mathrm{HCl}$ at room temperature $(303 \pm 1 \mathrm{~K})$ for $3 \mathrm{~h}$ in beakers with different solutions-one was a blank solution without inhibitor and others were with inhibitors (methanolic ginseng fruit extract with 100, 200, 300, 400, 500, 600, 700, 800, 900 and 1000 ppm). After 3 h of exposure in an acidic corrosive environment, the metal specimens were taken out and weighed after cleaning and drying as per the American Society for Testing and Materials (ASTM) specification. Loss in weight was calculated from the difference between initial and final weights for all the specimens. Then, the corrosion inhibition efficiency (IE \%) was obtained from the following expression [46-48].

$$
\begin{gathered}
\operatorname{IE}(\%)=\left(W_{0}-W_{i}\right) /\left(W_{0}\right) \times 100 \\
\theta=(I E \%) / 100
\end{gathered}
$$

where $W_{0}$ is the loss in weight without inhibitor and $W_{i}$ is the loss in weight with inhibitor.

\subsubsection{Temperature Studies}

The same weight loss measurement was carried out to understand the behavior of the inhibitor by increasing the temperature from room temperature to 313, 323, 333 and $343 \pm 1 \mathrm{~K}$. The specimens were dipped in $1 \mathrm{M} \mathrm{HCl}$ solution with and without inhibitor for $3 \mathrm{~h}$ at various temperatures, as mentioned above. Then, the weight loss of each specimen 
was noted and the corresponding efficiency was calculated. The inhibitor was prepared from ginseng fruit extract with methanol as a solvent at different concentrations from 100 to $1000 \mathrm{ppm}$.

\subsubsection{Field Emission Scanning Electron Microscope (FESEM) and EDX Studies}

The surface of the corroded metal specimen was observed using an FESEM to understand the difference between corroded and non-corroded specimens. To achieve this, a copper specimen with a $1-\mathrm{cm}^{2}$ surface area was immersed in $1 \mathrm{M} \mathrm{HCl}$ solution for $3 \mathrm{~h}$ and the specimen was taken out and washed in distilled water. After drying, the specimen was scanned in an FESEM (LEO-1530 Model) for morphology studies. In the same acidic environment, the specimen was immersed in $1000 \mathrm{ppm}$ concentration of inhibitor and the same procedure was repeated to study the morphology of the specimen. EDX studies were performed (Bruker, Germany,FlatQuard Model) to find out the composition of the products formed on the copper metal surface due to corrosion with and without inhibitor. In this study, a micro-analyzer electron probe was used to examine thin film coatings that formed on the metal surface to explore the chemical compositions on the cropped metal samples on the copper surface with and without inhibitor [49].

\subsubsection{Atomic Force Microscopy (AFM) Analysis}

The surface morphology of the copper specimen with surface area of $1 \mathrm{~cm}^{2}$ was scanned using a scanning probe microscope (SPM (Dimension ICON, Bruker; measurement mode: AFM)). To prepare the samples for this study the copper specimens were dried after exposure to $1 \mathrm{M} \mathrm{HCl}$ solution without and with inhibitor of $1000 \mathrm{ppm}$ concentration for $3 \mathrm{~h}$ at room temperature $(303 \pm 1 \mathrm{~K})$. The scanned images of the surface of the copper specimen can be interpreted for the effectiveness of the inhibitor. The surface roughness factor can also be derived for inhibited and uninhibited copper metal from the AFM analysis [50].

\subsection{Statistical Analysis}

All experiments were repeated thrice to ensure accurate results. The data were expressed as mean \pm standard error. One-way ANOVA analysis followed by the Duncan's test was used to determine significant $(p \leq 0.05)$ differences. SPSS Ver. 20 (SPSS Inc., Chicago, IL, USA) statistical software was used to compute the statistical tests.

\section{Results}

\subsection{Estimation of Total Phenols and Flavonoids}

The total phenolic contents of $P$. ginseng parts were analyzed using the Folin-Ciocalteu reagent method and a remarkable content was found in all three samples (Table 1). Among the three samples (root, leaf and fruit) of P. ginseng, the highest concentration of TPC was observed in the methanolic fruit extract $(95.21 \mathrm{mg} / \mathrm{g})$. The second-highest concentration was found in methanolic leaf extract $(39.21 \mathrm{mg} / \mathrm{g})$, which was followed by root $(30.21 \mathrm{mg} / \mathrm{g})$. The overall total phenols quantified followed the order fruit $>$ leaf $>$ root of methanolic extract. In all the samples analyzed, methanolic fruit extract was considerably better than leaf or root. The combined lowest total phenol concentration was observed in ginseng extracted with water $(42.05 \mathrm{mg} / \mathrm{g})$ consolidating all three parts. The total flavonoid content was found to be high in methanolic fruit extract $(50.21 \mathrm{mg} / \mathrm{g})$, followed by leaf $(24.32 \mathrm{mg} / \mathrm{g})$ and then root $(20.25 \mathrm{mg} / \mathrm{g})$. In all three samples, methanol was identified as a more efficient extraction medium than the other solvents (ethanol, ethyl acetate, acetone and water) since the overall flavonoid content was highest $(94.78 \mathrm{mg} / \mathrm{g})$ in methanol extract. A potential second solvent for the extraction of phenolic and flavonoid compounds was identified as ethanol, which produced significant amount of phenols (133.93 mg/g) and flavonoids $(82.08 \mathrm{mg} / \mathrm{g})$ in the total of leaf, fruit and root (Table 1$)$. 
Table 1. Total phenolic content (TPC) and total flavonoid content (TFC) of white Panax ginseng in five different solvents.

\begin{tabular}{|c|c|c|c|c|c|c|c|c|}
\hline \multirow{2}{*}{ Extract } & \multicolumn{4}{|c|}{ TPC (mg/g) } & \multicolumn{4}{|c|}{ TFC (mg/g) } \\
\hline & Leaf & Fruit & Root & Total & Leaf & Fruit & Root & Total \\
\hline Methanol & $39.21 \pm 4.32^{\mathrm{e}}$ & $95.21 \pm 8.21^{a}$ & $30.21 \pm 2.21 \mathrm{~g}$ & 164.63 & $24.32 \pm 3.58^{c}$ & $50.21 \pm 6.21^{a}$ & $20.25 \pm 3.58^{\mathrm{e}}$ & 94.78 \\
\hline Ethanol & $33.25 \pm 2.32^{f}$ & $72.46 \pm 4.21^{b}$ & $28.22 \pm 3.21^{h}$ & 133.93 & $23.54 \pm 4.20^{c}$ & $41.33 \pm 4.54^{b}$ & $17.21 \pm 2.87^{\mathrm{f}}$ & 82.08 \\
\hline Ethyl acetate & $25.55 \pm 2.55^{\mathrm{i}}$ & $66.51 \pm 3.55^{c}$ & $18.11 \pm 3.25^{\mathrm{k}}$ & 110.17 & $16.21 \pm 1.85^{\mathrm{f}, \mathrm{g}}$ & $21.95 \pm 2.87^{d}$ & $11.25 \pm 2.01^{i, j}$ & 49.41 \\
\hline Acetone & $11.33 \pm 3.02^{1}$ & $42.05 \pm 5.21^{\mathrm{d}}$ & $07.21 \pm 1.22 \mathrm{~m}$ & 60.59 & $12.22 \pm 1.58^{i}$ & $15.05 \pm 2.98^{\mathrm{g}, \mathrm{h}}$ & $10.55 \pm 1.52^{i, j}$ & 37.82 \\
\hline Water & $12.66 \pm 1.25^{1}$ & $22.35 \pm 2.32^{j}$ & $08.21 \pm 2.55^{\mathrm{m}}$ & 43.22 & $10.25 \pm 0.89^{k}$ & $14.32 \pm 1.87^{\mathrm{h}}$ & $09.52 \pm 1.05^{k}$ & 34.09 \\
\hline
\end{tabular}

The values presented are the mean \pm SEM. The superscripts in each mean represent significant $p$ values $(p<0.05)$ that are different from each other.

\subsection{Quantification of Phenolic Compounds}

A total of 23 phenolic compounds, including derivatives, were identified by using UHPLC (Table 2 and Figure 1).

Table 2. Major phenolic compounds identified in the different parts of P. ginseng extract by UHPLC analysis.

\begin{tabular}{|c|c|c|c|c|}
\hline \multirow{2}{*}{ Com. } & \multicolumn{4}{|c|}{ Concentration $(\mu \mathrm{g} / \mathrm{g})$} \\
\hline & Leaf & Fruit & Root & Total \\
\hline${ }^{*} p \mathrm{CA}$ & $125.24 \pm 3.32^{b}$ & $65.3 \pm 3.51^{\mathrm{e}}$ & $14.2 \pm 0.87^{\mathrm{c}}$ & 204.77 \\
\hline${ }^{*} \mathrm{FA}$ & $6.35 \pm 1.21^{\mathrm{i}}$ & $19.5 \pm 1.55^{\mathrm{i}}$ & $6.55 \pm 0.21^{\mathrm{e}}$ & 32.42 \\
\hline${ }^{*} m \mathrm{CA}$ & $185.32 \pm 2.85^{\mathrm{a}}$ & $45.2 \pm 2.35^{f}$ & $5.64 \pm 1.22^{\mathrm{e}}$ & 236.17 \\
\hline$* o \mathrm{CA}$ & $2.01 \pm 1.02^{\mathrm{j}, \mathrm{k}}$ & $1.55 \pm 0.24^{1}$ & $0.55 \pm 0.09^{\mathrm{f}}$ & 4.11 \\
\hline$* \mathrm{CA}$ & $43.21 \pm 4.32^{\mathrm{e}}$ & $1002.2 \pm 5.65^{\mathrm{a}}$ & $90.2 \pm 4.45^{\mathrm{a}}$ & 1135.63 \\
\hline \#\# MY & nd & nd & nd & - \\
\hline${ }^{\# \#} \mathrm{QC}$ & $2.00 \pm 0.87 \mathrm{j}, \mathrm{k}$ & nd & nd & 2.00 \\
\hline$\#$ KF & nd & nd & nd & - \\
\hline$* *$ GLA & nd & nd & nd & - \\
\hline$* * \mathrm{PA}$ & $35.21 \pm 1.55^{\mathrm{f}}$ & $6.98 \pm 1.54^{\mathrm{k}}$ & $10.2 \pm 2.10^{\mathrm{d}}$ & 52.44 \\
\hline$* *$ SA & nd & $75.3 \pm 3.25^{d}$ & $6.12 \pm 0.55^{\mathrm{e}}$ & 81.44 \\
\hline$* * \mathrm{GA}$ & $62.30 \pm 1.55^{\mathrm{d}}$ & $854.21 \pm 1.87^{b}$ & $65.2 \pm 2.01^{b}$ & 981.72 \\
\hline${ }^{\#} \mathrm{RU}$ & $65.54 \pm 4.21^{\mathrm{c}}$ & $165.32 \pm 3.99^{c}$ & $8.54 \pm 1.22^{d}$ & 239.4 \\
\hline${ }^{\#} \mathrm{VA}$ & $3.55 \pm 1.00^{\mathrm{j}}$ & $22.3 \pm 1.98^{h}$ & $6.32 \pm 0.10^{\mathrm{e}}$ & 32.2 \\
\hline${ }^{\#} \mathrm{RV}$ & $1.21 \pm 0.23^{\mathrm{k}}$ & nd & $1.54 \pm 0.77^{\mathrm{f}}$ & 2.75 \\
\hline${ }^{\#} \mathrm{NG}$ & $1.85 \pm 0.25 \mathrm{j}, \mathrm{k}$ & $11.2 \pm 1.22^{j}$ & $1.55 \pm 0.88^{f}$ & 14.65 \\
\hline${ }^{\#} \mathrm{FN}$ & $0.55 \pm 0.02^{k}$ & $0.98 \pm 0.07^{1}$ & $0.59 \pm 0.05^{\mathrm{f}}$ & 2.12 \\
\hline${ }^{\#} \mathrm{BA}$ & nd & nd & nd & - \\
\hline${ }^{\#} p \mathrm{HA}$ & $8.65 \pm 1.52^{h}$ & $35.2 \pm 3.02 \mathrm{~g}$ & $15.2 \pm 1.55^{c}$ & 59.07 \\
\hline${ }^{\#} \mathrm{NA}$ & $6.32 \pm 0.55^{\mathrm{i}}$ & $18.5 \pm 2.87^{\mathrm{i}}$ & $9.11 \pm 1.22^{d}$ & 33.98 \\
\hline${ }^{\#} t \mathrm{CA}$ & $1.55 \pm 0.55^{\mathrm{k}}$ & $1.02 \pm 0.21^{1}$ & $2.11 \pm 0.94^{\mathrm{f}}$ & 4.68 \\
\hline${ }^{\#} \mathrm{CN}$ & $15.32 \pm 1.55^{\mathrm{g}}$ & nd & $9.32 \pm 1.99^{d}$ & 24.64 \\
\hline${ }^{\#} \mathrm{HP}$ & $1.55 \pm 0.33^{k}$ & $2.54 \pm 0.44^{1}$ & $1.01 \pm 0.08^{\mathrm{f}}$ & 5.10 \\
\hline Total & 567.73 & 2327.52 & 254.04 & 3149.29 \\
\hline
\end{tabular}

Compounds-Com.; ${ }^{*}$-Coumaric acid $-{ }^{*} p \mathrm{CA} ;{ }^{*}$ Ferulic acid- ${ }^{*} \mathrm{FA} ;{ }^{*} m$-Coumaric acid- ${ }^{*} m \mathrm{CA}$; ${ }^{*} o$-Coumaric acid- ${ }^{*} \mathrm{CA} ;{ }^{*}$ Chlorogenic acid— ${ }^{*} \mathrm{CA} ;{ }^{\# \#}$ Myricetin- ${ }^{* \#} \mathrm{MY} ;{ }^{\# \#}$ Quercetin — ${ }^{\# \#} \mathrm{QC}$,

\#\# Kaempferol—\# KF; ${ }^{* *}$ Gallic acid—** GLA; ${ }^{* *}$ Protocatechuic acid—** PA; ${ }^{* *}$ Syringic acid—** SA; ** Gentisic acid—** GA; ${ }^{*}$ Rutin— ${ }^{*} \mathrm{RU}$; ${ }^{*}$ Vanillin — ${ }^{\text {VA; }}$ " Resveratrol—\# RV; Naringenin——

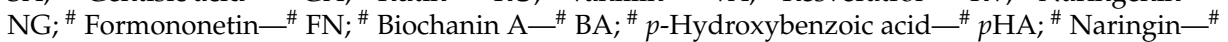
NA; " trans-Cinnamic acid- ${ }^{\#} t \mathrm{CA} ;{ }^{\#}$ Catechin - ${ }^{*} \mathrm{CN} ;{ }^{\#}$ Hesperetin- ${ }^{\#} \mathrm{HP}$; nd-non-detected. * Hydroxycinnamic acid; \#\# Flavonols; ${ }^{* *}$ Hydroxybenzoic acid and \# Other phenolic compounds. 'Values within a column with the same letters are not significantly different at the 0.05 level, as determined by Duncan's multiple range test. 
<smiles>O=C(O)/C=C/c1ccc(O)cc1</smiles><smiles>O=C(O)/C=C/c1cccc(O)c1</smiles><smiles>O=C(/C=C/c1ccc(O)c(O)c1)O[C@H]1C[C@@](O)(C(=O)O)C[C@H](O)[C@H]1O</smiles>

d<smiles>O=C(O)c1ccc(O)c(O)c1</smiles><smiles>COc1cc(C(=O)O)cc(OC)c1O</smiles><smiles>O=C(O)c1cc(O)ccc1O</smiles><smiles>O=C(O)c1ccc(O)cc1</smiles><smiles>CC1OC2OCC3OC(Oc4c(-c5ccc(O)c(O)c5)oc5cc(O)cc(O)c5c4=O)C(OC2C(O)C1O)C(O)C(O)C(O)C(O)C(O)C(O)C(O)C3O</smiles>

Figure 1. Chemical structure of major phenolic compounds in P. ginseng extract: (a) $p$-coumaric acid; (b) $m$-coumaric acid; (c) chlorogenic acid; (d) protocatechuic acid; (e) syringic acid; (f) gentisic acid; (g) p-hydroxybenzoic acid; and (h) rutin.

As already shown by the TPC and TFC, this analysis also revealed the presence of a high concentration of phenolic constituents in P. ginseng fruit $(2327.52 \mu \mathrm{g} / \mathrm{g})$ followed by leaf $(567.73 \mu \mathrm{g} / \mathrm{g})$ and root $(254.04 \mu \mathrm{g} / \mathrm{g})$. The most abundant phenol was identified as chlorogenic acid $(1002.2 \mu \mathrm{g} / \mathrm{g})$. Gentisic acid was the second-most abundant, with the highest value in the fruit $(854.21 \mu \mathrm{g} / \mathrm{g})$. These were followed by $m$-coumaric acid$185.32 \mu \mathrm{g} / \mathrm{g}$ (leaf); rutin-165.32 $\mathrm{gg} / \mathrm{g}$ (fruit); -coumaric acid- $125.24 \mu \mathrm{g} / \mathrm{g}$ (leaf); chloro-

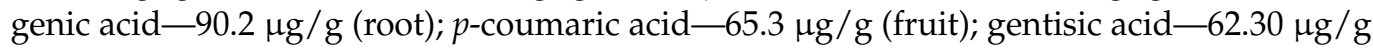
(leaf); syringic acid-75.3 $\mu \mathrm{g} / \mathrm{g}$ (fruit); and $m$-coumaric acid- $-45.2 \mu \mathrm{g} / \mathrm{g}$ (fruit). Only trace amounts of flavonols were found, whereas hydroxycinnamic acid, hydroxybenzoic acid and the total phenolic compounds were found present in a significant amount. 


\subsection{Antioxidant Assays}

The nitric oxide free radical was scavenged by the plant concentrates to different extents. The reduction of nitrate to nitrite was detected through the measurement of the change in absorbance intensity of "Griess reagent", a colored azo dye, at $546 \mathrm{~nm}$. Excellent activity was found at $1000 \mu \mathrm{g} / \mathrm{mL}$ in methanolic extract of fruit $(93 \%)$, followed by leaf $(88 \%)$ and root $(85 \%)$, and the effects were dose-dependent. The lowest activity $(30 \%)$ was found after treatment with $100 \mu \mathrm{g} / \mathrm{mL}$ water extract. The scavenging was recorded as $30-93 \%$ for samples against concentrations between 100 and $1000 \mu \mathrm{g} / \mathrm{mL}$ (Figure 2).
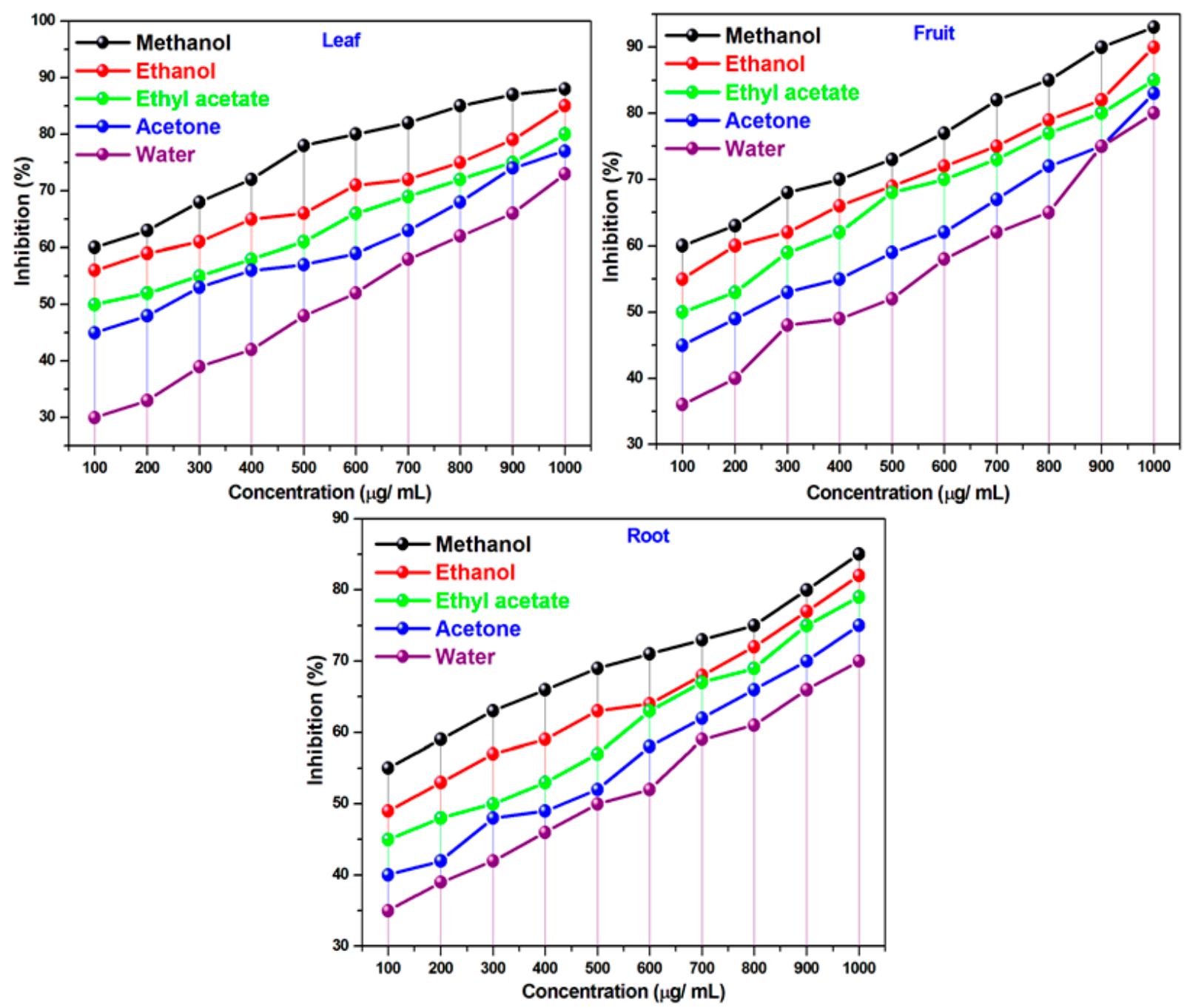

Figure 2. Nitric oxide assay of $P$. ginseng.

Out of the three parts of ginseng samples, the fruits produced greater scavenging action, followed by the leaf and then the root.

The antioxidant features of the plant extracts were studied through the percentage scavenging activity of the hydrogen peroxide free radical. In this assay, the methanolic extract of fruit $(86 \%)$ showed more activity at $1000 \mu \mathrm{g} / \mathrm{mL}$. The inhibition percentage was concentration-dependent. The methanolic extracts of fruits revealed higher activity and the lowest activity $(26 \%)$ was seen in the water extract of leaf and root at $100 \mu \mathrm{g} / \mathrm{mL}$. Thus, the scavenging activity was concluded to have dose-dependent effects, ranging from $26 \%$ to $86 \%$ against $100-1000 \mu \mathrm{g} / \mathrm{mL}$ of extract concentration (Figure 3 ). 

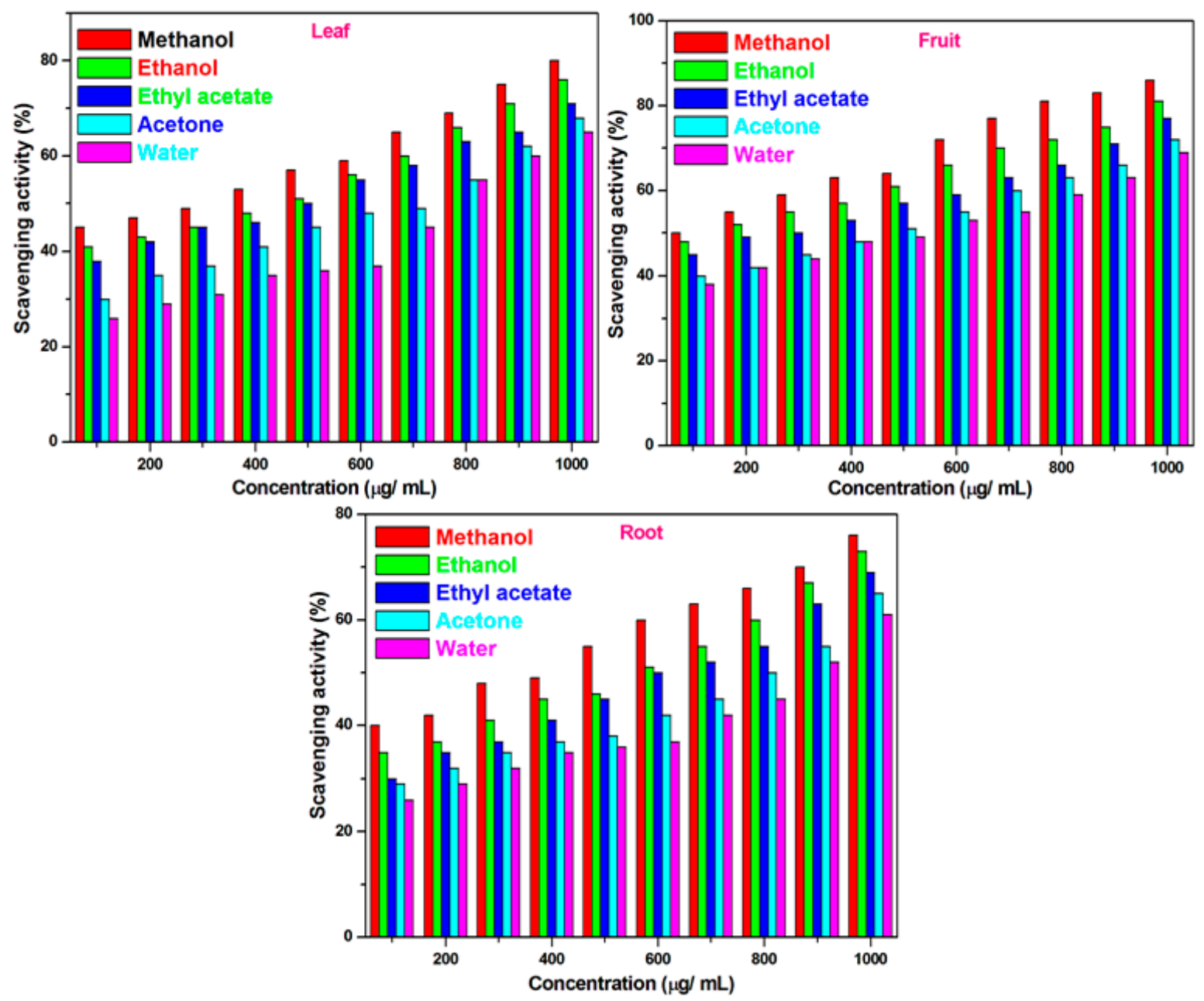

Figure 3. Hydrogen peroxide scavenging activity of P. ginseng.

The change in the color of samples after the reduction of molybdenum (Mo (VI) to Mo (V)) was indicated by the intensity of the green color at $765 \mathrm{~nm}$ and was used as a measure of the antioxidant activity. This assay showed the strongest effect of the methanolic extract, in the order (fruit) $1395 \pm 0.77>$ (leaf) $1255 \pm 0.54>$ (root) $1159 \pm 0.32$. The lowest antioxidant activity was found in the water extract of all three parts (fruits, leaf and root) in the range from $899 \pm 0.52$ to $1002 \pm 0.55$ (Table 3).

Table 3. Determined by the phosphomolybdenum method of $P$. ginseng.

\begin{tabular}{cccc}
\hline Solvents & Leaf & Fruit & Root \\
\hline Methanol & $1255.54 \pm 3.57^{\mathrm{c}}$ & $1395.77 \pm 3.85^{\mathrm{a}}$ & $1159.32 \pm 1.98^{\mathrm{d}}$ \\
Ethanol & $1159.24 \pm 2.52^{\mathrm{d}}$ & $1300.38 \pm 2.07^{\mathrm{b}}$ & $1100.78 \pm 2.08^{\mathrm{e}}$ \\
Ethyl acetate & $1010.66 \pm 2.32^{\mathrm{f}}$ & $1252.95 \pm 3.88^{\mathrm{c}}$ & $1058.34 \pm 3.23^{\mathrm{f}}$ \\
Acetone & $985.21 \pm 0.04^{\mathrm{g}}$ & $1100.66 \pm 1.21^{\mathrm{e}}$ & $952.31 \pm 2.05^{\mathrm{g}}$ \\
Water & $901.59 \pm 1.22^{\mathrm{h}}$ & $1002.55 \pm 2.21^{\mathrm{f}}$ & $899.52 \pm 1.88^{\mathrm{h}}$ \\
\hline
\end{tabular}

The values presented are the mean \pm SEM. The superscripts in each mean represent significant $p$ values $(p<0.05)$ that are different from each other.

\subsection{Corrosion Studies}

\subsubsection{Weight Loss Measurements}

From the weight loss measurements, loss in weight of each specimen was calculated, and from that, the percentage of inhibition efficiency was determined from Equations (1) and (2), and the results are tabulated in Table 4. From Table 4, it was noted that the 
inhibition efficiency of methanolic fruit extracted from ginseng fruit extract was increased by increasing the concentration at room temperature $(303 \pm 1 \mathrm{~K})$, since methanol solvent extracts more TPC and TFC compared to other solvents, namely ethanol, ethyl acetate, acetone and water, to achieve higher antioxidant and antibacterial properties in fruit extract. Hence, methanolic fruit extract of ginseng is optimized as a corrosion inhibitor for copper. At a 1000-ppm concentration, the inhibitor attains a maximum efficiency of $96 \%$ from $50 \%$ efficiency obtained at $100 \mathrm{ppm}$.

Table 4. Inhibition efficiency (IE \%) for different concentrations (Conc.) of methanolic fruit extract of $P$. ginseng for corrosion of copper in $1 \mathrm{M} \mathrm{HCl}$ at different temperatures (303-343 $\pm 1 \mathrm{~K})$.

\begin{tabular}{|c|c|c|c|c|c|c|c|c|c|c|c|c|c|c|c|}
\hline \multirow{3}{*}{$\begin{array}{l}\text { Conc. } \\
\text { (ppm) }\end{array}$} & \multicolumn{15}{|c|}{ Temperatures ( $\pm \mathbf{1}$ K) } \\
\hline & \multicolumn{3}{|c|}{303} & \multicolumn{3}{|c|}{313} & \multicolumn{3}{|c|}{323} & \multicolumn{3}{|c|}{333} & \multicolumn{3}{|c|}{343} \\
\hline & $\theta$ & IE \% & $\sigma^{a}$ & $\theta$ & IE \% & $\sigma^{a}$ & $\theta$ & IE \% & $\sigma^{a}$ & $\theta$ & IE \% & $\sigma^{a}$ & $\theta$ & IE \% & $\sigma^{\mathrm{a}}$ \\
\hline 100 & 0.50 & 50 & 0.2 & 0.45 & 45 & 0.2 & 0.44 & 44 & 0.2 & 0.38 & 38 & 0.6 & 0.30 & 30 & 0.2 \\
\hline 200 & 0.60 & 60 & 0.1 & 0.55 & 55 & 0.3 & 0.53 & 53 & 0.5 & 0.45 & 45 & 0.2 & 0.32 & 32 & 0.3 \\
\hline 300 & 0.65 & 65 & 0.5 & 0.63 & 63 & 0.5 & 0.60 & 60 & 0.1 & 0.51 & 51 & 0.3 & 0.35 & 35 & 0.1 \\
\hline 400 & 0.72 & 72 & 0.6 & 0.70 & 70 & 0.1 & 0.65 & 65 & 0.4 & 0.56 & 56 & 0.1 & 0.41 & 41 & 0.4 \\
\hline 500 & 0.80 & 80 & 0.1 & 0.76 & 76 & 0.8 & 0.70 & 70 & 0.3 & 0.62 & 62 & 0.5 & 0.44 & 44 & 0.1 \\
\hline 600 & 0.85 & 85 & 0.5 & 0.80 & 80 & 0.3 & 0.73 & 73 & 0.6 & 0.67 & 67 & 0.8 & 0.46 & 46 & 0.2 \\
\hline 700 & 0.88 & 88 & 0.2 & 0.83 & 83 & 0.1 & 0.79 & 79 & 0.2 & 0.70 & 70 & 0.1 & 0.50 & 50 & 0.1 \\
\hline 800 & 0.90 & 90 & 0.1 & 0.87 & 87 & 0.2 & 0.80 & 80 & 0.1 & 0.72 & 72 & 0.2 & 0.52 & 52 & 0.3 \\
\hline 900 & 0.93 & 93 & 0.3 & 0.85 & 85 & 0.1 & 0.83 & 83 & 0.2 & 0.75 & 75 & 0.1 & 0.55 & 55 & 0.2 \\
\hline 1000 & 0.96 & 96 & 0.5 & 0.90 & 90 & 0.3 & 0.85 & 85 & 0.2 & 0.77 & 77 & 0.5 & 0.60 & 60 & 0.2 \\
\hline
\end{tabular}

\subsubsection{Temperature Studies}

The loss in weight of copper specimens in an acidic environment at varying temperatures with and without inhibitor was measured from weight loss measurement, and the corresponding inhibition efficiency was calculated and is presented in Table 5. This table represents the inhibition efficiency of the plant extract at increasing temperature from 303 to $343 \pm 1 \mathrm{~K}$ for various concentrations from 100 to $1000 \mathrm{ppm}$. From the table, it was noted that the maximum inhibition efficiency at 1000-ppm concentration at room temperature was $96 \%$ and the efficiency was noted as $90 \%, 85 \%, 77 \%$ and $60 \%$ at every $10 \pm 1 \mathrm{~K}$ increment in temperature.

Table 5. Surface composition of copper before and after immersion in $1 \mathrm{M} \mathrm{HCl}$, with and without 1000 ppm inhibitor.

\begin{tabular}{ccc}
\hline \multirow{2}{*}{ Elements } & \multicolumn{2}{c}{ Copper Specimen (wt \%) } \\
\cline { 2 - 3 } & Without Inhibitor & With Inhibitor \\
\hline $\mathrm{C}$ & 07.13 & 04.11 \\
$\mathrm{O}$ & 13.54 & 08.64 \\
$\mathrm{Cu}$ & 78.32 & 87.25 \\
$\mathrm{Cl}$ & 01.01 & - \\
\hline
\end{tabular}

\subsubsection{FESEM and EDX Studies}

Field emission scanning electron microscope (FESEM) and energy-dispersive X-ray (EDX) analysis techniques were used to determine the elements in $P$. ginseng extract. Figure 4 depicts the FESEM images of corroded copper specimens without and with optimized inhibitor (1000 ppm of methanolic fruit extract of ginseng). From the images, one can easily observe the corroded surface of the copper specimen when exposed to an acidic medium from the damage, pits and scratches in the absence of inhibitor (Figure 4a). However, the surface image of the specimen that experienced the same acidic environment in the presence of the inhibitor shows a smooth and clear surface without discoloration 
(Figure $4 \mathrm{~b}$ ). It proves that there is no initiation of corrosion taking place on the specimen exposed to an acid environment with inhibitor. Figure 5 depicts the EDX spectra which present the elements that exist in copper dipped in $1 \mathrm{M} \mathrm{HCl}$ and copper dipped in $1 \mathrm{M}$ $\mathrm{HCl}$ with $1000 \mathrm{ppm}$ of inhibitor prepared from P. ginseng plant extract. Table 5 presents the elements present on the surface of the copper specimen that underwent acid corrosion $(1 \mathrm{M} \mathrm{HCl})$ without and with inhibitor (1000 ppm of ginseng plant extract).

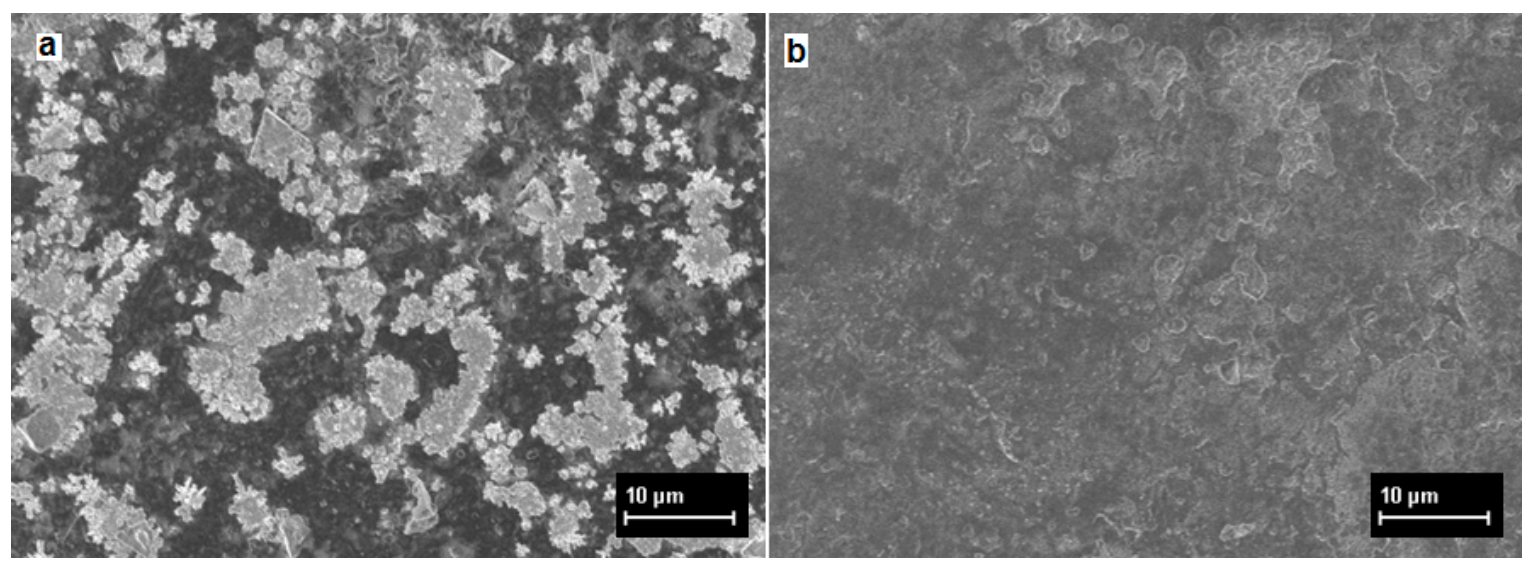

Figure 4. Field emission scanning electron microscope (FESEM) micrographs of copper dipped in (a) $1 \mathrm{M} \mathrm{HCl}$ and (b) $1 \mathrm{M}$ $\mathrm{HCl}$ with 1000 ppm of inhibitor.
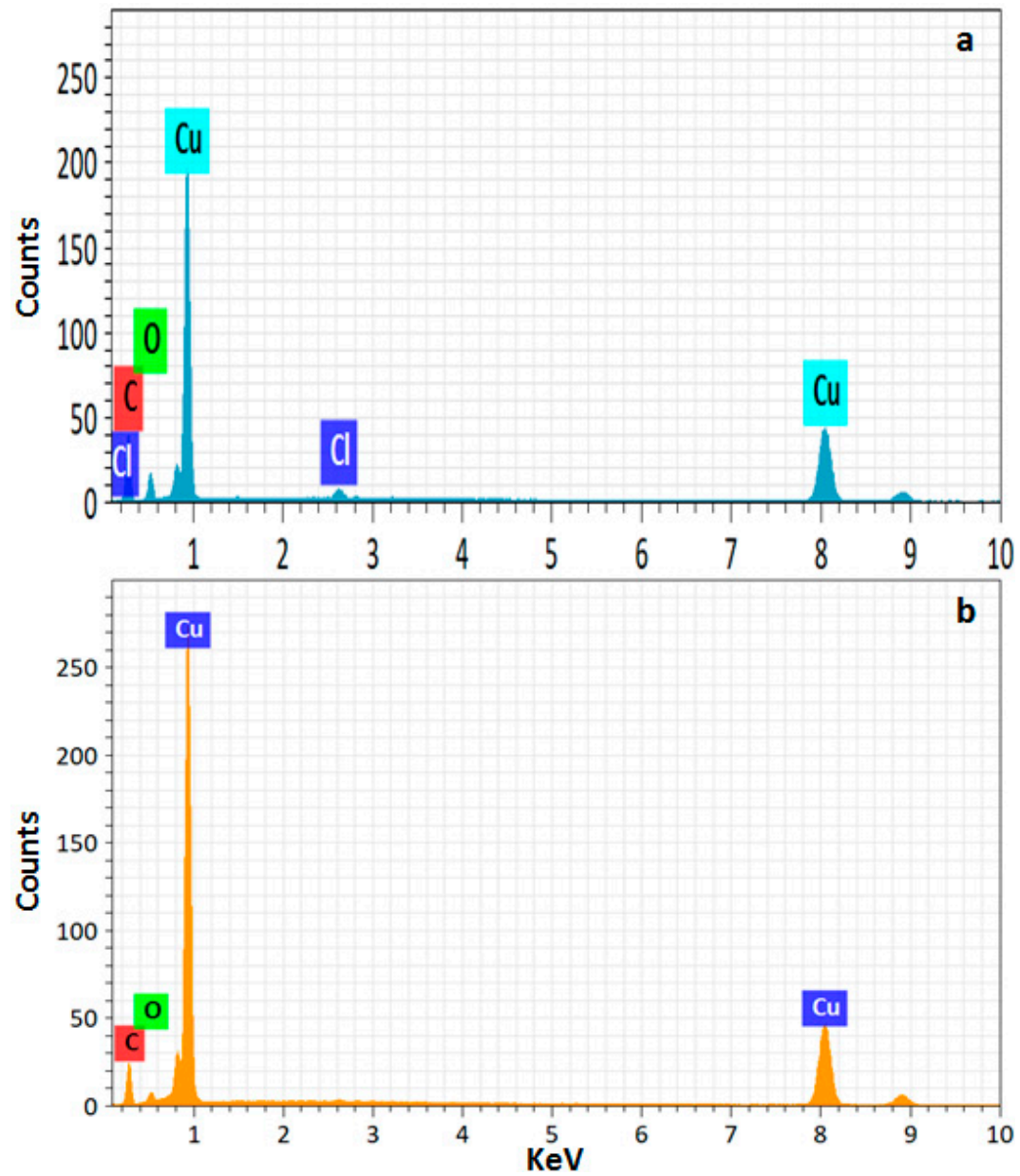

Figure 5. Energy-dispersive X-ray spectroscopy (EDX) spectra of copper dipped in (a) $1 \mathrm{M} \mathrm{HCl}$ and (b) $1 \mathrm{M} \mathrm{HCl}$ with 1000 ppm of inhibitor. 


\subsubsection{AFM Analysis}

An AFM analysis was performed to study the surface morphology of corroded copper metal surfaces with and without inhibitor in $1 \mathrm{M} \mathrm{HCl}$ solution. Figure 6 shows the twodimensional AFM images of copper surfaces which were exposed in $1 \mathrm{M} \mathrm{HCl}$ either without inhibitor or with $1000 \mathrm{ppm}$ of $P$. ginseng inhibitor. Figure 6a depicts the image of the unprotected copper specimen without inhibitor and Figure $6 \mathrm{~b}$ reflects the image of the protected specimen with the ginseng plant extract as a corrosion inhibitor. In the absence of the inhibitor, due to speedy corrosion and deformation, high roughness is attributed. AFM is not only used for providing high-resolution images but can also be used to calculate surface roughness of a metal surface. Data about copper surface morphology derived from AFM images are helpful for understanding the corrosion process.

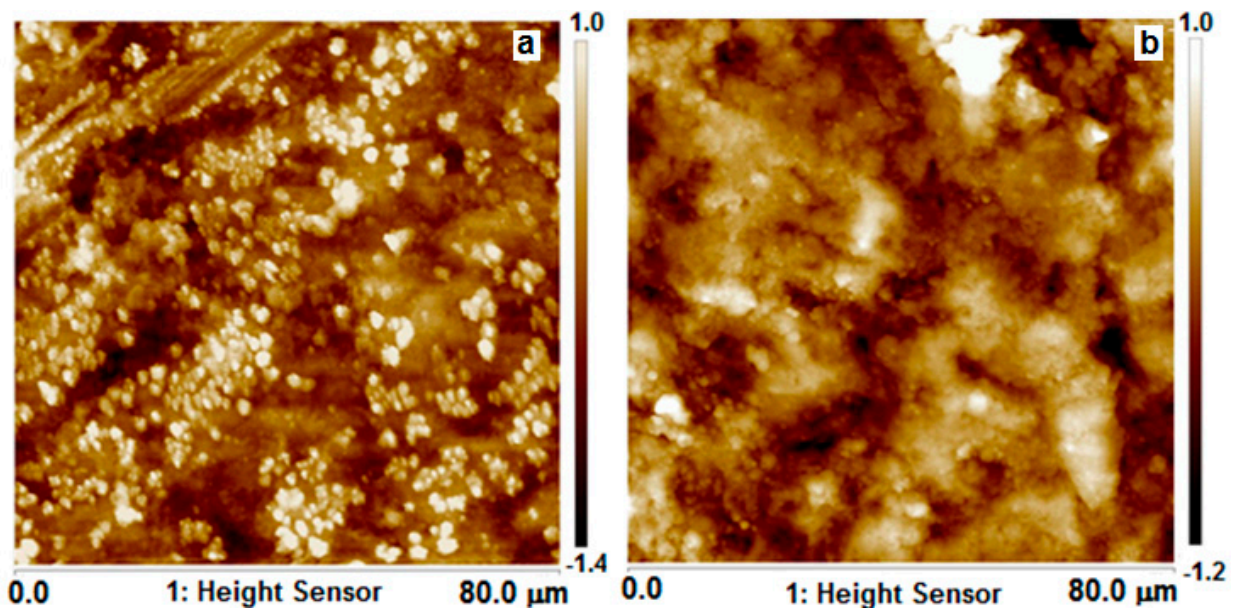

Figure 6. Two-dimensional atomic force microscopy (AFM) images of copper (a) in $1 \mathrm{M} \mathrm{HCl}$, and (b) in $1 \mathrm{M} \mathrm{HCl}$ with 1000 ppm of P. ginseng inhibitor.

\section{Discussion}

The total phenol and flavonoid contents of the methanolic extracts of samples were considerably higher in P. ginseng, which provided evidence that ginseng is the most potent variety. In this research, the results highlighted the importance of ginseng fruits which contain high levels of phenols and flavonoids. Out of five solvents, the methanolic extraction of plant parts, especially fruits, was previously documented to contain a high content of phenols and strong antioxidant ability [51]. The different solvents tried in this study gave a clear understanding of the importance of the selection of reliable and suitable solvents to achieve optimum extraction of total phenol and flavonoid from P. ginseng [51]. These components are strongly reducing, which enables them to act as free radical scavengers. The antioxidants help to protect humans from harmful oxidants, thereby safeguarding macromolecules such as proteins, lipids, DNA and carbohydrates to improve the immune system [52]. The present study supports the specific selection of solvents to extract more phenols. The analysis of phenolic compounds such as hydroxycinnamic acid, hydroxybenzoic acid and flavonols was conducted through UHPLC as certified by previous research $[53,54]$. Many plant parts, from the roots to the fruits, are known to produce numerous secondary metabolites that have several medicinal uses, such as Low-Density Lipoprotein (LDL) oxidation inhibition and reduced hypertension, and are also helpful for the improvement of many neurological disorders $[55,56]$. Although many studies on ginsenosides have already been performed, very few studies have used UHPLC to comparatively evaluate the phenolic content of the various parts of ginseng. This study has helped to estimate the different phenols present in ginseng and may assist in the bulk production of pharmacologically important compounds from ginseng.

Many researchers have identified the capacity of plant-based antioxidants as efficient free radical scavengers [57-59]. Components such as kaempferol, quercetin, gallic acid, 
cinnamic acid, rutin, coumaric acid and resveratrol were proven to have various therapeutic applications. As these are plant-derived components, their inclusion in our daily diet has the potential to inhibit free radicals [60-62]. These components have shown potency as reductants and singlet oxygen quenchers found in fruits and vegetables grown in varying climatic conditions and extracted by different methods [63]. Several techniques have been used to study the antioxidant mechanism of the plant extracts. The use of three different antioxidant assays in this research emphasized the importance of ginseng fruit as a potential antioxidant. The selection of methanol as a solvent resulted in greater activity than the rest of the solvents because of its compatibility with $P$. ginseng. This shows the crucial role of solvent selection in order to obtain more phenols and flavonols from the plant samples [64].

Nitric oxide is well known for its inflammatory action. However, the excessive production of free radicals damaging tissues, vascular collapses and other medical illness such as juvenile diabetes and ulcerative colitis may occur [65]. The nitric oxide content of sodium nitroprusside produces nitrite when reacted with oxygen, which exhibits free radical scavenging activity.

Antioxidant property was observed in the methanolic extract of fruits, leaves and roots, demonstrating it as an equivalent scavenging compound. As a weak oxidant, hydrogen peroxide inactivates enzymes by oxidizing thiol (-SH) groups, which cross the cell membrane and react with ferrous ions to form hydroxyl free radicals, leading to cell toxicity [66]. The results shown in this research are encouraging and confirm the scavenging activity of ginseng extracts, especially $P$. ginseng fruit parts [66,67]. The change in color is equivalent to the concentration of the sample. The antioxidant ability of flavonoids such as quercetin and rutin had been extensively reported, conferring protection of liver cells, inflammation, carcinogenesis and smooth muscles [68,69].

The anti-corrosive property of ginseng was confirmed due to the presence of phenolic compounds present in the extract, which are very active compounds adsorbed on the surface of the specimen, forming a protective film around the surface of the metal [70]. A thick, stable and well-bonded layer formed by the inhibitor was the reason for attaining higher efficiency at 1000-ppm concentration [26]. Due to high temperature, the stable compounds adsorbed on the surface are desorbed at some points and bring down the corrosion efficiency [71]. From SEM images, it was observed that without ginseng extract, the surface of the copper metal was seriously attacked by the $\mathrm{HCl}$ medium and formed severe roughness, pits and scratches. At the same time, a smooth copper surface without any damages was noted; due to the physical adsorption of ginseng extract molecules, a protective layer was formed over the metal surface and confirmed that the copper is well protected from corrosive ions. From the EDX spectra of copper metal after attack of $\mathrm{HCl}$ solution without inhibitor, it is noted that due to the surface contamination, there are some residual elements; $\mathrm{C}-7.13 \%, \mathrm{O}-13.54 \%$ and $\mathrm{Cl}-1.01 \%$ were present on the surface of the copper specimen, which are more than that on the specimen with inhibitor, and there was no existence of $\mathrm{Cl}$ on the inhibited specimen. Presence of $\mathrm{Cu}$ is about $9 \%$ lower in the corroded specimen without the inhibitor because of removal of copper from the surface due to corrosion. Furthermore, $37 \%$ less $\mathrm{O}$ content represents that there was less oxidation in the inhibited specimen, which is the root cause for corrosion. The plant extract as a corrosion inhibitor formed a shielding layer on the metal surface which protected the copper from getting delaminated and removal of layer of metal surface. Furthermore, the presence of carbon and oxygen on the inhibited metal surface proves that the active chemical compounds are adsorbed on the copper surface by a synergistic effect and shows a higher inhibition efficiency. There are three ways of achieving adsorptionphysical, chemical and combined [72]. Physical adsorption is nothing but the phenomenon of electrostatic interaction of protonated molecules with already adsorbed sulfur ions; chemical adsorption is the interaction between unshared electron pairs of oxygen atoms or $\pi$-electrons of aromatic ring copper surface (Figure 7). The inhibition process is executed, hindering the plant extract solution from forming a film around the metal surface, and by 
the action of adsorption, the available cathodic and anodic sites which activate corrosion are minimized [73,74]. The roughness and damage on the corroded copper specimen under the exposure of $\mathrm{HCl}$ medium are due to the absence of the inhibitor. In the presence of the inhibitor, it is very clear from the topography of the AFM image that there was no corrosion initiation and the smooth surface without any pits and damage confirms that the thin film that formed on the surface of the copper metal protected it from corrosion (Figure 7). The surface roughness value is high in the blank solution ( $329 \mathrm{~nm})$, that is, in $\mathrm{HCl}$ medium without the inhibitor, because of the corroded surface of the copper metal, whereas the roughness value decreased to about $55 \mathrm{~nm}$ in copper exposed to same acid environment with the inhibitor which is $16.7 \%$ less than that of the uninhibited corroded specimen [75-81].

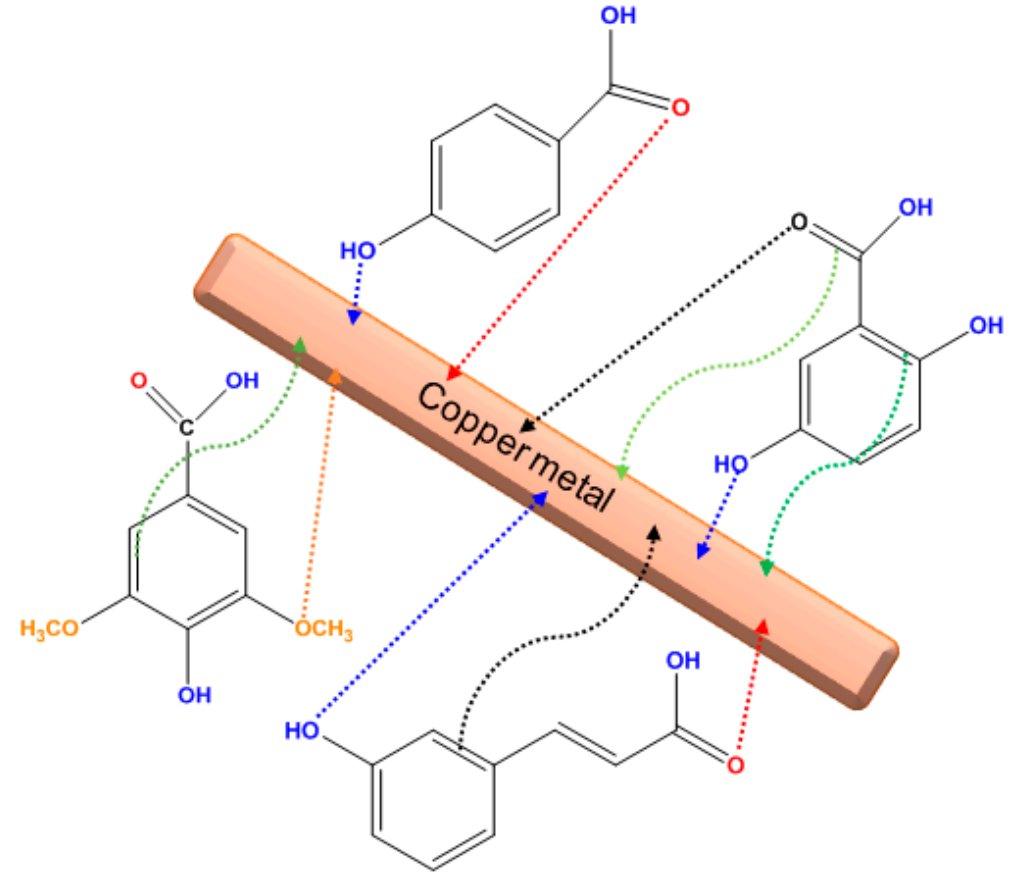

Figure 7. Mechanism of corrosion inhibition.

\section{Conclusions}

This research supports the known health benefits of the identified phytochemicals of ginseng. As it is used as a traditional medicine and food in many countries, the inclusion of ginseng in a regular diet is a simple task. Regular usage of ginseng will eventually lead to the improvement of various aspects of human health as it contains numerous antioxidants and confers other therapeutic effects. Owing to these scientifically proven activities, ginseng can be commercially cultivated for the extraction and isolation of target compounds for clinical purposes. The rapid development of novel, effective methods for the isolation and identification of new plant-based compounds will enable the further study of ginseng to elute more compounds of therapeutic importance. About $96 \%$ corrosion inhibition efficiency was achieved with methanolic fruit extract of ginseng at a 1000ppm concentration at room temperature. In addition to the antioxidant and antibacterial properties of ginseng, its anti-corrosive property was also confirmed from the FESEM images and the surface composition of the EDX spectra conducted on a copper specimen exposed to an acidic environment. Two-dimensional images and the surface roughness factor obtained from AFM studies prove the corrosion resistance ability of ginseng plant extract.

Author Contributions: Conceptualization, methodology, investigation, data interpretation, and original draft preparation, R.M., M.P., and I.-M.C.; methodology, data interpretation, and validation, R.M., K.K., and S.-H.K.; project administration, funding acquisition, conception and design of the 
study, and writing, review, and editing of the manuscript for submission, M.P., R.M., and S.-H.K. All authors have read and agreed to the published version of the manuscript.

Funding: This work was supported by the National Research Foundation of Korea (NRF) grant funded by the Korea government (MSIT) (No. 2017R1E1A1A01075282) and was written as part of Konkuk University's research support program for its faculty on sabbatical leave in 2019.

Institutional Review Board Statement: Not applicable.

Informed Consent Statement: Not applicable.

Conflicts of Interest: The authors declare no conflict of interest.

\section{References}

1. Yang, J.; Yeo, I. A study on the origins of 'Korean ginseng'. Korean J. Med. Hist. 2004, 13, 1-19.

2. Baeg, I.; So, S. The world ginseng market and the ginseng (Korea). J. Ginseng Res. 2013, 37, 1-7. [CrossRef] [PubMed]

3. Hu, S.Y. The genus Pananx (ginseng) in Chinese medicine. Econ. Bot. 1976, 30, 11-28. [CrossRef]

4. Yun, T. Panax ginseng-a non-organ-specific cancer preventive. Lancet Oncol. 2001, 2, 49-55. [CrossRef]

5. Tran, N.; Tran, M.; Truong, H.; Le, L. Spray-drying microencapsulation of high concentration of bioactive compounds fragments from Euphorbia hirta L. extract and their effect on diabetes mellitus. Foods 2020, 9, 881. [CrossRef] [PubMed]

6. Salehi, B.; Selamoglu, Z.; Sener, B.; Kilic, M.; Jugran, A.K.; Tommasi, N.; Sinisgalli, C.; Milella, L.; Rajkovic, J.; Morais-Braga, M.F.B.; et al. Berberis plants-drifting from farm to food applications, phytotherapy, and phytopharmacology. Foods $2019,8,522$. [CrossRef]

7. Sritalahareuthai, V.; Temviriyanukul, P.; On-nom, N.; Charoenkiatkul, S.; Suttisansanee, U. Phenolic profiles, antioxidant, and inhibitory activities of Kadsura heteroclita (Roxb.) Craib and Kadsura coccinea (Lem.) A.C. Sm. Foods 2020, 9, 1222. [CrossRef] [PubMed]

8. Turrini, F.; Donno, D.; Beccaro, G.L.; Pittaluga, A.; Grilli, M.; Zunin, P.; Boggia, R. Bud-derivatives, a novel source of polyphenols and how different extraction processes affect their composition. Foods 2020, 9, 1343. [CrossRef]

9. Apak, R.; Güçlü, K.; Demirata, B.; Özyürek, M.; Çelik, S.E.; Bektaşoğlu, B.; Işıl Berker, K.; Özyurt, D. Comparative evaluation of various total antioxidant capacity assays applied to phenolic compounds with the CUPRAC assay. Molecules 2007, 12, 1496-1547. [CrossRef]

10. Kang, K.S.; Yamabe, N.; Kim, H.Y.; Okamoto, T.; Sei, Y.; Yokozawa, T. Increase in the free radical scavenging activities of American ginseng by heat processing and its safety evaluation. J. Ethnopharmacol. 2007, 113, 225-232. [CrossRef]

11. Attele, A.S.; Wu, J.A.; Yuan, C.S. Ginseng pharmacology: Multiple constituents and multiple actions. Biochem. Pharmacol. 1999, 58, 1685-1693. [CrossRef]

12. Kim, H.; Oh, I.; Park, K.H.; Kim, N.M.; Do, J.H.; Cho, Y. Stimulatory effect of dietary red ginseng on epidermal hydration and ceramide levels in ultraviolet-irradiated hairless mice. J. Med. Food 2009, 12, 746-754. [CrossRef] [PubMed]

13. Sun, B.S.; Gu, L.J.; Fang, Z.M.; Wang, C.Y.; Wang, Z.; Lee, M.R.; Li, Z.; Li, J.J.; Sung, C.K. Simultaneous quantification of 19 ginsenosides in black ginseng developed from Panax ginseng by HPLC-ELSD. J. Pharm. Biomed. Anal. 2009, 50, 15-22. [CrossRef] [PubMed]

14. Chen, C.; Chiou, W.; Zhang, J. Comparison of the pharmacological effects of Panax ginseng and Panax quinquefolium. Acta Pharmacol. Sin. 2008, 29, 1103-1108. [CrossRef]

15. Kang, S.; Min, H. Ginseng, the 'Immunity Boost': The effects of Panax ginseng on immune system. J. Ginseng Res. 2012, 36, 354-368. [CrossRef]

16. Lee, S.M.; Bae, B.; Park, H.; Ahn, N.; Cho, B.; Cho, Y.; Kwak, Y. Characterization of Korean red ginseng (Panax ginseng Meyer): History, preparation method, and chemical composition. J. Ginseng Res. 2015, 39, 384-391. [CrossRef]

17. Xue, Q.; He, N.; Wang, Z.; Fu, X.; Aung, L.H.H.; Liu, Y.; Li, M.; Cho, J.Y.; Yang, Y.; Yu, T. Functional roles and mechanisms of ginsenosides from Panax ginseng in atherosclerosis. J. Ginseng Res. 2020. [CrossRef]

18. Li, X.; Mo, N.; Li, Z. Ginsenosides: Potential therapeutic source for fibrosis-associated human diseases. J. Ginseng Res. 2020, 44, 386-398. [CrossRef]

19. Song, H.; Park, J.; Choi, K.O.; Lee, J.; Chen, J.; Park, H.J.; Yu, B.I.; Iida, M.; Rhyu, M.R.; Lee, Y.J. Ginsenoside Rf inhibits cyclooxygenase-2 induction via peroxisome proliferatoreactivated receptor gamma in A549 cells. J. Ginseng Res. 2019, 43, 319-325. [CrossRef]

20. Kang, S.; Im, K.; Kim, G.; Min, H. Antiviral activity of 20(R)-ginsenoside Rh2 against murine gamma herpesvirus. J. Ginseng Res. 2017, 41, 496-502. [CrossRef]

21. Kim, B.; Jeon, Y.K.; Kim, C.W. Kaposi sarcoma herpes virus-associated hemophagocytic syndrome complicated by multicentric castleman disease and kaposi sarcoma in a HIV-negative immunocompetent patient: An autopsy case. J. Korean Med. Sci. 2009, 24, 970-974. [CrossRef] [PubMed]

22. Dittmer, D.P.; Richards, K.L.; Damania, B. Treatment of Kaposi sarcoma-associated herpesvirus-associated cancers. Front. Microbiol. 2012, 3, 141. [CrossRef] [PubMed] 
23. Khadraoui, A.; Khelifa, A.; Hachama, K.; Mehdaoui, R. Thymus algeriensis extract as new eco-friendly corrosion inhibitor for 2024 aluminium alloy in 1M HCl medium. J. Mol. Liq. 2016, 214, 293-297. [CrossRef]

24. Shabani-Nooshabadi, M.; Hoseiny, F.S.; Jafari, Y. Green approach to corrosion inhibition of copper by the extract of Calligonum comosum in strong acidic medium. Metall. Mater. Trans. A 2015, 46, 293-299. [CrossRef]

25. Jmiai, A.; El-Ibrahimi, B.; Tara, A.; Oukhrib, R.; El-Issami, S.; Jbara, O.; Bazzi, L.; Hilali, M. Chitosan as an eco-friendly inhibitor for copper corrosion in acidic medium: Protocol and characterization. Cellulose 2017, 24, 3843-3867. [CrossRef]

26. Ashassi-Sorkhabi, H.; Seifzadeh, D.; Hosseini, M.G. EN, EIS and polarization studies to evaluate the inhibition effect of 3Hphenothiazin-3-one, 7-dimethylamin on mild steel corrosion in $1 \mathrm{M} \mathrm{HCl}$ solution. Corros. Sci. 2008, 50, 3363-3370. [CrossRef]

27. Cai, L.; Fu, Q.; Shi, R.W.; Tang, Y.; Long, Y.T.; He, X.P.; Jin, Y.; Liu, G.X.; Chen, G.R.; Chen, K.X. 'Pungent' copper surface resists acid corrosion in strong $\mathrm{HCl}$ solutions. Ind. Eng. Chem. Res. 2014, 53, 64-69. [CrossRef]

28. Sherif, E.S.M. Corrosion behavior of copper in $0.5 \mathrm{M}$ hydrochloric acid pickling solutions and its inhibition by 3-amino-1,2,4triazole and 3-amino-5-mercapto-1,2,4-triazole. Int. J. Electrochem. Sci. 2012, 7, 1884-1897.

29. Loto, C.A.; Loto, R.T.; Oshogbunu, O.J. Corrosion inhibition effect of Allium sativum extracts on mild steel in $\mathrm{HCl}_{\text {and }} \mathrm{H}_{2} \mathrm{SO}_{4}$. J. Chem. Pharm. Res. 2016, 8, 216-230.

30. Deyab, M.A. Egyptian licorice extract as a green corrosion inhibitor for copper in hydrochloric acid solution. J. Ind. Eng. Chem. 2015, 22, 384-389. [CrossRef]

31. Mihajlović, M.B.P.; Antonijević, M.A. Copper corrosion inhibitors. Period. 2008-2014. A Review. Int. J. Electrochem. Sci. 2015, 10, 1027-1053.

32. Prabakaran, M.; Kim, S.H.; Kalaiselvi, K.; Hemapriya, V.; Chung, I.M. Highly efficient Ligularia fischeri green extract for the protection against corrosion of mild steel in acidic medium: Electrochemical and spectroscopic investigations. J. Taiwan Inst. Chem. Eng. 2016, 59, 553-562. [CrossRef]

33. Chauhan, J.S. Anticorrosion behaviour of Zenthoxylum alatum extract in acidic media. Asian J. Chem. 2009, 21, $1975-1978$.

34. Shah, A.M.; Rahim, A.A.; Hamid, S.A.; Yahya, S. Green inhibitors for copper corrosion by mangrove tannin. Int. J. Electrochem. Sci. 2013, 8, 2140-2153.

35. Shah, A.M.; Rahim, A.A.; Yahya, S.; Raja, P.B.; Hamid, S.A. Acid corrosion inhibition of copper by mangrove tannin. Pigm. Resin Technol. 2011, 40, 118-122. [CrossRef]

36. Rehan, H.H. Corrosion control by water-soluble extracts from leaves of economic plants. Materialwiss. Werkst. 2003, 34, $232-237$. [CrossRef]

37. Chung, I.; Kim, J.; Lee, J.; An, M.; Lee, K.; Park, S.; Kim, J.; Kim, M.; Kim, S. C/N/O/S stable isotopic and chemometric analyses for determining the geographical origin of Panax ginseng cultivated in Korea. J. Ginseng Res. 2018, 42, 485-495. [CrossRef]

38. Prabakaran, M.; Kim, S.H.; Hemapriya, V.; Chung, I.M. Tragia plukenetii extract as an eco-friendly inhibitor for mild steel corrosion in $\mathrm{HCl} 1 \mathrm{M}$ acidic medium. Res. Chem. Intermed. 2016, 42, 3703-3719. [CrossRef]

39. Liang, T.; Yue, W.; Li, Q. Comparison of the phenolic content and antioxidant activities of Apocynum venetum L. (Luo-Bu-Ma) and two of its alternative species. Int. J. Mol. Sci. 2010, 11, 4452-4464. [CrossRef]

40. Prabakaran, M.; Kim, S.H.; Hemapriya, V.; Chung, I.M. Evaluation of polyphenol composition and anti-corrosion properties of Cryptostegia grandiflora plant extract on mild steel in acidic medium. J. Ind. Eng. Chem. 2016, 37, 47-56. [CrossRef]

41. Prabakaran, M.; Kim, S.H.; Hemapriya, V.; Gopiraman, M.; Kim, I.S.; Chung, I.M. Rhus verniciflua as a green corrosion inhibitor for mild steel in $1 \mathrm{M} \mathrm{H}_{2} \mathrm{SO}_{4}$. RSC Adv. 2016, 6, 57144-57153. [CrossRef]

42. Prabakaran, M.; Kim, S.H.; Sasireka, A.; Chandrasekaran, M.; Chung, I.M. Polyphenol composition and antimicrobial activity of various solvent extracts from different plant parts of Moringa oleifera. Food Biosci. 2018, 26, 23-29. [CrossRef]

43. Boora, F.; Chirisa, E.; Mukanganyama, S. Evaluation of nitrite radical scavenging properties of selected Zimbabwean plant extracts and their phytoconstituents. J. Food Process. Preserv. 2014, 2014, 1-7. [CrossRef]

44. Hazra, B.; Biswas, S.; Mandal, N. Antioxidant and free radical scavenging activity of Spondias pinnata. BMC Complement. Altern. Med. 2008, 8, 1-10. [CrossRef]

45. Khan, R.A.; Khan, M.R.; Sahreen, S.; Ahmed, M. Assessment of flavonoids contents and in vitro antioxidant activity of Launaea procumbens. Chem. Cent. J. 2012, 6, 1-11. [CrossRef] [PubMed]

46. Chung, I.M.; Kim, S.H.; Prabakaran, M. Evaluation of phytochemical, polyphenol composition and anti-corrosion capacity of Cucumis anguria L. leaf extract on metal surface in sulfuric acid medium. Prot. Met. Phys. Chem. Surf. 2020, 56, 214-224. [CrossRef]

47. Chung, I.M.; Malathy, R.; Kim, S.H.; Kalaiselvi, K.; Prabakaran, M.; Gopiraman, M. Ecofriendly green inhibitor from Hemerocallis fulva against aluminum corrosion in sulphuric acid medium. J. Adhes. Sci. Technol. 2020, 34, 1483-1506. [CrossRef]

48. Prabakaran, M.; Kim, S.H.; Sasireka, A.; Kalaiselvi, K.; Chung, I.M. Polygonatum odaratum extract as an eco-friendly inhibitor for aluminum corrosion in acidic medium. J. Adhes. Sci. Technol. 2018, 32, 2054-2069. [CrossRef]

49. Devi, G.N.; Unnisa, C.B.N.; Roopan, S.M.; Hemapriya, V.; Chitra, S.; Chung, I.M.; Kim, S.H.; Prabakaran, M. Floxacins: As mediators in enhancing the corrosion inhibition efficiency of natural polymer dextrin. Macromol. Res. 2020, 28, 558-566. [CrossRef]

50. Anitha, R.; Unnisa, C.B.N.; Hemapriya, V.; Roopan, S.M.; Chung, I.M.; Kim, S.H.; Prabakaran, M. Anti-corrosive potential of Cyperus rotundus as a viable corrosion inhibitor for mild steel in sulphuric acid. Pigment Resin Technol. 2020, 49, 295-304. [CrossRef]

51. Melichácová, S.; Timoracká, M.; Bystrická, J.; Vollmannová, A.; Céry, J. Relation of total antiradical activity and total polyphenol content of sweet cherries (Prunus avium L.) and tart cherries (Prunus cerasus L.). Acta Agric. Slov. 2010, 95, 21-28. [CrossRef] 
52. Atoui, A.K.; Mansouri, A.; Boskou, G.; Kefalas, P. Tea and herbal infusions: Their antioxidant activity and phenolic profile. Food Chem. 2005, 89, 27-36. [CrossRef]

53. Prabakaran, M.; Kim, S.H.; Mugila, N.; Hemapriya, V.; Parameswari, K.; Chitra, S.; Chung, I.M. Aster koraiensis as nontoxic corrosion inhibitor for mild steel in sulfuric acid. J. Ind. Eng. Chem. 2017, 52, 235-242. [CrossRef]

54. Tripoli, E.; Guardia, M.L.; Giammanco, S.; Majo, D.D.; Giammanco, M. Citrus flavonoids: Molecular structure, biological activity and nutritional properties: A review. Food Chem. 2007, 104, 466-479. [CrossRef]

55. Sannomiya, M.; Fonseca, V.B.; Silva, M.A.D. Flavonoids and antiulcerogenic activity from Byrsonima crassa leaves extracts. J. Ethnopharmacol. 2005, 97, 1-6. [CrossRef]

56. Chung, I.M.; Malathy, R.; Priyadharshini, R.; Hemapriya, V.; Kim, S.H.; Prabakaran, M. Inhibition of mild steel corrosion using Magnolia kobus extract in sulphuric acid medium. Mater. Today Commun. 2020, 25, 101687. [CrossRef]

57. Kulisica, T.; Radonicb, A.; Katalinicc, V.; Milos, M. Use of different methods for testing antioxidative activity of oregano essential oil. Food Chem. 2004, 85, 633-640. [CrossRef]

58. Sowndhararajan, K.; Kang, S.C. Free radical scavenging activity from different extracts of leaves of Bauhinia vahlii Wight \& Arn. Saudi J. Biol. Sci. 2013, 20, 319-325.

59. Vlaisavljevića, S.; Šibula, F.; Sinkab, I.; Zupkob, I.; Ocsovszkid, I.; Jovanović-Šantaa, S. Chemical composition, antioxidant and anticancer activity of licorice from Fruska Gora locality. Ind. Crop. Prod. 2018, 112, 217-224. [CrossRef]

60. Brewer, M.S. Natural antioxidants: Sources, compounds, mechanisms of action, and potential applications. Compr. Rev. Food Sci. Food Saf. 2011, 10, 221-247. [CrossRef]

61. Khanduja, K.L. Stable free radical scavenging and antiperoxidative properties of resveratrol in vitro compared with some other bioflavonoids. Indian J. Biochem. Biophys. 2003, 40, 416-422. [PubMed]

62. Ozsoy, N.; Candoken, E.; Akev, N. Implications for degenerative disorders: Antioxidative activity, total phenols, flavonoids, ascorbic acid, beta-carotene and beta-tocopherol in Aloe vera. Oxidative Med. Cell Longev. 2009, 2, 99-106. [CrossRef] [PubMed]

63. Ignat, I.; Volf, I.; Popa, I.V. A critical review of methods for characterisation of polyphenolic compoundsin fruits and vegetables. Food Chem. 2011, 126, 1821-1835. [CrossRef] [PubMed]

64. Rao, R. Phytochemicals as nutraceuticals-Global approaches to their role in nutrition and health in agricultural and biological sciences. In Biological Oxidations and Antioxidant Activity of Natural Products; Nunes, X.P., Silva, F.S., da Almeida, J.R.G., de Lima, J.T., de Araújo Ribeiro, L.A., Júnior, L.J.Q., Filho, M.B., Eds.; InTech: London, UK, 2012; pp. 1-20.

65. Jan, S.; Khan, M.R.; Rashid, U.; Bokhari, J. Assessment of antioxidant potential, total phenolics and flavonoids of different solvent fractions of Monotheca buxifolia fruit. Osong Public Health Res. Perspect. 2013, 4, 246-254. [CrossRef] [PubMed]

66. Miller, M.J.; Sadowska-Krowicka, H.; Chotinaruemol, S.; Kakkis, J.L.; Clark, D.A. Amelioration of chronic ileitis by nitric oxide synthase inhibition. J. Pharmacol. Exp. Ther. 1993, 264, 11-16. [PubMed]

67. Prabakaran, M.; Hemapriya, V.; Kim, S.H.; Chung, I.M. Evaluation of antioxidant and anticorrosion properties of Epipremnum aureum. Arab. J. Sci. Eng. 2019, 44, 169-178. [CrossRef]

68. Jin, Y.; Kim, Y.; Jeon, J.; Wang, C.; Min, J.; Noh, H.; Yang, D. Effect of white, red and black ginseng on physicochemical properties and ginsenosides. Plant Food Hum. Nutr. 2015, 70, 141-145. [CrossRef] [PubMed]

69. Materska, M. Quercetin and its derivatives: Chemical structure and bioactivity-a review. Pol. J. Food Nutr. Sci. 2008, 58, 407-413.

70. Da-Quan, Z.; Li-Xin, G.; Guo-Ding, Z. Inhibition of copper corrosion in aerated hydrochloric acid solution by amino-acid compounds. J. Appl. Electrochem. 2005, 35, 1081-1085.

71. Narashima, R.; Bhat, J.I. Inhibition of copper corrosion by Arecanut seed extracts. Elixir Corros. Dye 2017, 106, 46449-46454.

72. Verma, C.; Ebenso, E.E.; Bahadur, I.; Quraishi, M.A. An overview on plant extracts as environmental sustainable and green corrosion inhibitors for metals and alloys in aggressive corrosive media. J. Mol. Liq. 2018, 266, 577-590. [CrossRef]

73. Hemapriya, V.; Prabakaran, M.; Parameswari, K.; Chitra, S.; Kim, S.H.; Chung, I.M. Experimental and theoretical studies on inhibition of benzothiazines against corrosion of mild steel in acidic medium. Anti Corros. Methods Mater. 2017, 64, 306-314. [CrossRef]

74. Chung, I.M.; Kim, S.H.; Hemapriya, V.; Kalaiselvi, K.; Prabakaran, M. Inhibition behavior of Tragia involucrata L. phenolic compounds against acidic medium corrosion in low carbon steel surface. Chin. J. Chem. Eng. 2019, 27, 717-725. [CrossRef]

75. Negm, N.A.; Kandile, N.G.; Badr, E.A.; Mohammed, M.A. Gravimetric and electrochemical evaluation of environmentally friendly nonionic corrosion inhibitors for carbon steel in $1 \mathrm{M} \mathrm{HCl}$. Corros. Sci. 2012, 65, 94-103. [CrossRef]

76. Manokarana, G.; Prabakaran, M. Evaluation of antioxidant and anticorrosion activities of Ligularia fischeri plant extract. Chem. Sci. Eng. Res. 2019, 1, 16-24. [CrossRef]

77. Chitra, S.; Chung, I.M.; Kim, S.H.; Prabakaran, M. A study on anticorrosive property of phenolic components from Pachysandra terminalis against low carbon steel corrosion in acidic medium. Pigment Resin Technol. 2019, 48, 389-396. [CrossRef]

78. Prabakaran, M.; Kim, S.H.; Oh, Y.T.; Raj, V.; Chung, I.M. Anticorrosion properties of momilactone A isolated from rice hulls. J. Ind. Eng. Chem. 2017, 45, 380-386. [CrossRef]

79. Anitha, R.; Chitra, S.; Hemapriya, V.; Chung, I.M.; Kim, S.H.; Prabakaran, M. Implications of eco-addition inhibitor to mitigate corrosion in reinforced steel embedded in concrete. Constr. Build. Mater. 2019, 213, 246-256. [CrossRef]

80. Prabakaran, M.; Kim, S.H.; Sasireka, A.; Hemapriya, V.; Chung, I.M. $\beta$-Sitosterol isolated from rice hulls as an efficient corrosion inhibitor for mild steel in acidic environments. New J. Chem. 2017, 41, 3900-3907. [CrossRef] 
81. Hemapriya, V.; Prabakaran, M.; Chitra, S.; Swathika, M.; Kim, S.H.; Chung, I.M. Utilization of biowaste as an eco-friendly biodegradable corrosion inhibitor for mild steel in $1 \mathrm{~mol} / \mathrm{L}$. HCl solution. Arab. J. Chem. 2020, 13, 8684-8696. [CrossRef] 